\title{
The Analysis of Potential Earthquake and Tsunami and The Relation to The Preparedness of Padang Society In 2019
}

\author{
Nopriadi $^{1}$, Septia Pristi Rahmah ${ }^{2}$, Emy Leonita ${ }^{3}$ \\ \{nopriadi@ph.unand.ac.id ${ }^{1}$, septiapristirahmah@ph.unand.ac.id ${ }^{3}$, \\ leonitaemy@yahoo.com $\left.{ }^{3}\right\}$ \\ 1,2,3 Faculty of Public Health, Andalas University, Indonesia
}

\begin{abstract}
The total area of Padang city is $7.613 \mathrm{Ha}$, and $19.41 \%$ of use this area is classified as the red zone area of Tsunami. This study was purposed to analyze society preparedness in the red zone in facing the earthquake and tsunami disaster in Padang City 2019. This study was by cross-sectional design in the red zone area of Padang from March to August 2019. There were 106 respondent and were selected by accidental sampling. Data were collected by questionnaire questionnaire. Data were analyzed using univariate and bivariate analysis with the Chi-Square test and level of confidence 95\%. Logistic regression was used for multivariate analysis. The univariate results show more than half $(56.6 \%)$ of citizen are not ready to against the earthquake and Tsunami, bivariate analysis shows that there was the relationship between the variable of knowledge $(p=0.017)$, education level $(p=0045)$, action $(p=0.000)$, and training $(p=0.000)$ with preparedness. Meanwhile the variable of attitude $(p=0,154)$, gender $(p=0,926)$, experience $(p=0,872)$ have no relationship with preparedness. Based on multivariate analysis, it was found that the dominant factor of preparedness is the training $(p=0,001)$. Based on research that has been done, training is the dominant factor against the preparedness of society in facing the earthquake and Tsunami, therefore it is expected to hold socialization programs and training that can be done periodically either in small or large scale.
\end{abstract}

Keyword: Earthquakes, Preparedness, Society, Tsunami

\section{Introduction}

Indonesia is one of the most vulnerable countries to natural disasters, especially the areas that passed by the plate tectonics in the western part of the Indian Ocean. In the west part of West Sumatra Coast, there can be found Mentawai Fault System (MFS). The western part of the island of Sumatra at an angle, it creates a pressure of this movement forming Sumatra Fault, also called as The Great Sumatran Fault.[1] Act No. 24 of 2007 about disaster management aims to protect the lives and livelihoods in the Republic of Indonesia from disaster by doing integrated disaster mitigation, that is organized, planned, coordinated, and integrated.[2] 
The City / Regency in West Sumatra that can be categorized as an earthquake and tsunamiprone are South Pesisir, Padang Pariaman, Mentawai Islands District, West Pasaman, Pariaman, and Padang ${ }^{[3]}$. West Sumatra in Disaster Prone Areas map (DPA) is dominated by the pink color (regions prone to high earthquake), which means it has a high potential for earthquake shocks with a higher intensity scale from VII MMI. One of factor why the earthquake often happened on the contact plate boundary and ocean crustal plate the islands at subduction zones is the oceanic plate that is moving northward relative perpendicular to the shape of Sumatra island at a speed of $6-7 \mathrm{~cm} /$ year $[4,5]$

Based on the tsunami hazard map by BNPB (Badan Nasional Penanggulangan Bencana) issued in 2013, there are 3 Tsunami hazard classes in Padang, which are high, medium, and low. In all areas of Padang, 7.613 hectares or $19.41 \%$ area of Padang included in high hazard areas. Based on research by Kristanti conducted in Hamlet Dishes Sidoharjo village, Bantul, Yogyakarta shows that people's experience of the earthquake on May 26, 2006, still leaving worry for the aftershock and Tsunami. Piring Village society preparedness against earthquake belongs to the "set category," with an average score of respondents overall value, which shows the number, 47. Based on the background above, researchers get interested in researching the analysis of the potential for earthquakes and tsunamis in the West Coast Region of Padang and the relation with society preparedness in the red zone area of Padang 2019.

\section{Method}

This study used a quantitative approach with the cross-sectional method. This research was conducted in the red zone area of Padang city from March to August in 2019. The number of samples in this study were 106 samples from 1.788 populations and taken using accidental sampling. Data were collected by interviewing the respondent through a questionnaire. Then, the data were analyzed using Chi-Square and regression logistic. Data in this study were processed from editing, coding, entry, and the last cleaning.

\section{Results}

The frequency distribution of variables that influence society preparedness for the earthquake and Tsunami can be seen in the following table:

Table 1 Related Factors of Society preparedness in facing the Earthquake and Tsunami disaster in Padang $2019(\mathrm{n}=106)$

\begin{tabular}{lll}
\hline Variables & Frequency (f) & Percentage (\%) \\
\hline Preparedness & & \\
$\quad$ Not ready & 60 & 56.6 \\
Ready & 46 & 43.4 \\
Knowledge & & \\
Low & 45 & 42.5 \\
High & 61 & 57.5 \\
Attitude & & \\
$\quad$ Negative & 51 & 48.1 \\
\hline
\end{tabular}




\begin{tabular}{lll}
\hline $\begin{array}{l}\text { Positive } \\
\text { Experience }\end{array} \quad 55$ & 51.9 \\
$\quad$ Less Experienced & 25 & 23.6 \\
$\quad$ Experienced & 81 & 76.4 \\
Education level & & \\
$\quad$ Low & 25 & 23.6 \\
$\quad$ High & 81 & 76.4 \\
Gender & \\
$\quad$ woman & 57 & 53.8 \\
Lai-man & 49 & 46.2 \\
Action & & \\
It is not following & 47 & 44.3 \\
$\quad$ Corresponding & 59 & 55.7 \\
Training & & \\
$\quad$ Never & 51 & 48.1 \\
Ever & 55 & 51.9 \\
\hline
\end{tabular}

According to table $1,56.6 \%$ (60 respondents) were not prepared to deal with a potential earthquake and Tsunami. The low knowledge obtained 42.5\% (45 respondents) public related to the earthquake and Tsunami. $48.1 \%$ (51 respondent) has a negative attitude in facing the potential earthquake and Tsunami. 23.6\% (25 respondents) had less experienced in dealing with the earthquake and Tsunami. The low educational level in facing the potential earthquake and Tsunami 23.6\% (25 respondents) and dominantly female 53.8\% (57 respondents). $44.3 \%$ (47 respondents) act inconsistently in the face of potential earthquakes and Tsunami. Moreover, $48.1 \%$ ( 51 respondents) never attended training in facing the earthquake and Tsunami.

Table 2 Relationship between Independent Variable and Dependent Variable

\begin{tabular}{|c|c|c|c|c|c|c|c|c|}
\hline \multirow{3}{*}{$\begin{array}{l}\text { Variables } \\
\text { Independent }\end{array}$} & \multicolumn{6}{|c|}{ Preparedness } & \multirow{3}{*}{$\begin{array}{l}\text { POR } \\
(95 \% \text { CI })\end{array}$} & \multirow{3}{*}{ p-value } \\
\hline & \multicolumn{2}{|c|}{ Not ready } & \multicolumn{2}{|c|}{ Ready } & \multicolumn{2}{|c|}{ Total } & & \\
\hline & $\mathrm{f}$ & $\%$ & $\mathrm{f}$ & $\%$ & $\mathrm{f}$ & $\%$ & & \\
\hline \multicolumn{9}{|l|}{ Knowledge } \\
\hline Low & 32 & 71.1 & 13 & 28.9 & 45 & 100 & \multirow{3}{*}{$\begin{array}{l}2.901 \\
(1,280- \\
6,574)\end{array}$} & \multirow{3}{*}{0,017} \\
\hline High & 28 & 45.9 & 33 & 54.1 & 61 & 100 & & \\
\hline Amount & 60 & 56.6 & 46 & 43.4 & 106 & 100 & & \\
\hline \multicolumn{9}{|l|}{ Attitude } \\
\hline Negative & 33 & 64.7 & 18 & 35.3 & 51 & 100 & \multirow{3}{*}{$\begin{array}{l}1.901 \\
(0,871- \\
4,150)\end{array}$} & \multirow{3}{*}{0,154} \\
\hline Positive & 27 & 49.1 & 28 & 50.9 & 55 & 100 & & \\
\hline Amount & 60 & 56.6 & 46 & 43.4 & 106 & 100 & & \\
\hline \multicolumn{9}{|l|}{ Experience } \\
\hline less-experienced & 15 & 60 & 10 & 40 & 25 & 100 & \multirow{3}{*}{$\begin{array}{l}1.200 \\
(0,482- \\
2,988)\end{array}$} & \multirow{3}{*}{0.872} \\
\hline Experienced & 45 & 55.6 & 36 & 44.4 & 81 & 100 & & \\
\hline Amount & 60 & 56.6 & 46 & 43.4 & 106 & 100 & & \\
\hline
\end{tabular}




\begin{tabular}{|c|c|c|c|c|c|c|c|c|}
\hline \multicolumn{9}{|l|}{ Education level } \\
\hline Low & 19 & $76 \%$ & 6 & $24 \%$ & 25 & 100 & \multirow{3}{*}{$\begin{array}{l}3.089 \\
(1,119- \\
8,533)\end{array}$} & \multirow{3}{*}{0.045} \\
\hline High & 41 & 50.6 & 40 & 49.4 & 81 & 100 & & \\
\hline Amount & 60 & 56.6 & 46 & 43.4 & 106 & 100 & & \\
\hline \multicolumn{9}{|l|}{ Gender } \\
\hline Woman & 33 & 57.9 & 24 & 42.1 & 57 & 100 & \multirow{3}{*}{$\begin{array}{l}1.120 \\
(0,519- \\
2,420)\end{array}$} & \multirow{3}{*}{0.926} \\
\hline Male & 27 & 55.1 & 22 & 44.9 & 49 & 100 & & \\
\hline Amount & 60 & 56.6 & 46 & 43.4 & 106 & 100 & & \\
\hline \multicolumn{9}{|l|}{ Action } \\
\hline $\begin{array}{l}\text { It is not in } \\
\text { accordance with }\end{array}$ & 37 & 78.7 & 10 & 21.3 & 47 & 100 & \multirow{3}{*}{$\begin{array}{l}5.791 \\
(2.420 \text { to } \\
13.861)\end{array}$} & \multirow{3}{*}{0,000} \\
\hline Corresponding & 23 & 39 & 36 & 61 & 59 & 100 & & \\
\hline Amount & 60 & 56.6 & 46 & 43.4 & 106 & 100 & & \\
\hline \multicolumn{9}{|l|}{ Training } \\
\hline Never & 41 & 80.4 & 10 & 19.6 & 51 & 100 & \multirow{3}{*}{$\begin{array}{l}7.768 \\
(3,200- \\
18,860)\end{array}$} & \multirow{3}{*}{0,000} \\
\hline Ever & 19 & 34.5 & 36 & 65.5 & 55 & 100 & & \\
\hline Amount & 60 & 56.6 & 46 & 43.4 & 106 & 100 & & \\
\hline
\end{tabular}

Based on table 2, the bivariate analysis shows the percentage of preparedness in which more people are not ready with low knowledge of $71.1 \%$. The statistical test result of both shows a significant relationship, where the p-value is 0.017 .

The bivariate analysis shows the percentage of preparedness in which more people are not ready with a negative attitude of $64.7 \%$. Statistical test results of both show no significant relationship, where the p-value is 0.154 .

And it shows the percentage of preparedness in which more people are not ready with less experienced $60 \%$. The results of statistical tests of both show no significant relationship, where the $\mathrm{p}$-value is 0.872 .

$76 \%$ of people with low education levels are not well-prepared. Statistical test results of both show a significant relationship, where the p-value is 0.045 .

The bivariate analysis also shows the percentage of preparedness in which more people are not ready are from females $(57.9 \%)$. Statistical test results of both show no significant relationship, where the p-value is 0.926 .

We can see from the table the percentage of preparedness in which more people are not ready with unsuitable action (78.7\%). Statistical test results of both show a significant relationship, where the p-value is 0.000 .

Based on the results, the bivariate analysis shows the percentage of preparedness in which more people are not ready for people who did not get training $(80.4 \%)$. Statistical test results between the two show a significant relationship, where the p-value is 0.000 . 
Table 3 The Dominant Variables that Influence the Preparedness of Disaster in Padang Society

\begin{tabular}{llll}
\hline Variables & $\mathrm{B}$ & $\mathrm{p}$-value & $95 \% \mathrm{Cl}$ \\
\hline Knowledge & .101 & .360 & $(-0.355)-(0.642)$ \\
Attitude & 0,062 & .530 & $(-0.133)-(0.256)$ \\
Education level & 0,156 & .128 & $(-0.045)-(0.357)$ \\
Action & 0,156 & 0.162 & $(-0.064)-(0.376)$ \\
training & 0.342 & 0,001 & $(0.148)-(0.642)$ \\
\hline
\end{tabular}

Table 3 shows that the training variable has a significant relationship with the society in disaster preparedness at Purus Padang with p-value $0.001(<0.05)$. Variables (knowledge, attitudes, education, and action) have no significant relationship with disaster preparedness because it has a $p$-value $>0.05$.

\section{Discussion}

Preparedness is an event that is done by the public to anticipate disasters to prevent loss of life and property. In facing disaster, preparedness is a major factor in determining people's safety, so it needs participation from all of the parties to participate directly[2], [6]. According to the research, $56.6 \%$ of people at Purus were not ready to deal with earthquakes and Tsunami. Therefore, we have to increase the preparedness through a well-scheduled program and conduct regarding the issues. So it creates a complex and can be sustainable in order to anticipate the disaster and avoid unwanted loss.

Knowledge can influence the characters of people, including in facing disaster. Based on the results about knowledge of the earthquake and Tsunami in Purus region, $42.5 \%$ of people had low knowledge of facing disaster. Knowledge is the result of "know" and happen after a person make sense of an object, so that knowledge can influence people action. Based on this theory, we can conclude the level of knowledge respondents were in understanding level, not at action level.

People are expected to have knowledge until on the evaluation level, not just know, but also understand and can implement it. So people can assess their willingness and capabilities and capacities of the public to get knowledge about the earthquake and Tsunami to be ready in facing the threat of disaster[7].

Attitudes are an enclosed response from someone to object. Attitudes can be influenced by a trust/confidence, ideas, and concepts to an object, evaluation on the object as well as a propensity to act. Based on the results of research on attitudes toward earthquake in Padang society, less than half of respondents, $48.1 \%$ had a negative attitude. It is expected the efforts to increase the positive attitude of society to face up the earthquake and Tsunami. The efforts to improve these attitudes can be made by providing disaster-related information and counseling are held regularly and not only held after such disasters[8].

Experience in facing earthquakes can show the real consequences of such an event. A traumatic event will generate a different perception between individuals from one to another. Based on the research, the earthquake, and Tsunami experience in Purus regional society, 23.6\% of people had less experience in dealing with the earthquake and Tsunami. Improving experience for society can be done in many ways like social media, leaflets, advertising, and 
regular information.

The education level of the society in this study shows $23.6 \%$ of people with low education levels. Another study done by Gouzeva stated $83.5 \%$ of students are interested in learning about disaster preparedness compared with those who are not interested. So that, to improve the society's education level in the future, promotional efforts are needed in the earthquake and tsunami preparedness, both promotions such as posters in public facilities or health services as well as from the mass media[9].

Based on the research, there were $53.8 \%$ and $46.2 \%$ of women in Purus regional society. Based on Law No. 24 the Year 2007 on Disaster Management, there is the principle that emphasizes that all of the programs on disaster management does not discriminate against individuals based on cultural background, gender, status, religion, and race. However, due to gender roles, there is a need for more sensitive and different intervention methods according to the respective gender roles, although the final goal is justice and equality in participating in preparedness and disaster efforts[2].

Action is a response or reaction to stimulus concrete person or object. This response is in the form of action (action) involving psychomotor aspects, or someone has practiced what is known or addressed. Based on the research results obtained in Padang Purus community, 44.3\% do improper acts in facing the earthquake and tsunami disaster. To make a positive attitude into a real action required supporting factors such as facilities and support from other parties[10].

Training is one way to prepare for something that must be anticipated and sought to reduce the risk. $48.1 \%$ respondent Purus community have never attended training in disaster preparedness. The training is needed to be done, especially to communities within the red zone. It can be done regularly or on request.

Statistical test results show that a significant relationship between knowledge and society preparedness in facing the earthquake and Tsunami, the p-value is 0.017 . The results are consistent with research conducted by Susilawati 2015 in Bantul; there is a relationship between knowledge and preparedness to face up earthquake and Tsunami [11]. There is a relationship between knowledge and disaster preparedness in facing disaster [12]. The action greatly influences knowledge, include the act in preparedness to face up the disaster. Good knowledge of respondents can minimize the impact of the disaster.

Statistical test results show that no significant relationship between the attitude of the society preparedness in facing the earthquake and Tsunami, the p-value is 0.154 . The result of this study is similar to Ahmad's research (2007), that there is a significant relationship between attitudes to disaster preparedness. Alhusna (2007) also found a significant relationship between attitudes to disaster preparedness. Attitudes are enclosed response from someone against something. Attitudes can be influenced by a lack of trust/confidence, ideas, and concepts to an object, the object, as well as the evaluation of a propensity to act [13].

From the analysis it show that no significant relationship between experience with society preparedness against earthquake and Tsunami, in which p-value is 0.872 . This is in contrast to the research conducted by Havwina 2018 that states there is a significant relationship between experience with disaster preparedness. In addition, research by Iffa in 2012 stated the experience have a relationship with society preparedness in facing the threat of earthquakes and tsunamis. The experience of society can not be a yardstick to distinguish society preparedness for disasters [14], [15].

This study found that a significant correlation between education level and society preparedness in facing the earthquake and Tsunami, the p-value is 0.045 . This study is in line with that made by Pokharel (2017) in Nepal education has a significant relationship to disaster preparedness with a p-value is 0.01 , respectively. It is also in line with research conducted by 
Syahrizal in 2013 stating that the level of education related to society preparedness in the face of the devastating earthquake and Tsunami $[16,17]$,

There is no significant relationship between gender and society preparedness against earthquake and Tsunami with the p-value is 0.926 . Based on the results of the statistical test known percentage of preparedness was not ready more to the society with $57.9 \%$ of the female sex. It is not in line with research conducted by Bikar 2018, which states that women have better knowledge than male teachers in the face of the earthquake[18],

The analysis shows a significant correlation between the actions of the society preparedness against earthquake and Tsunami, in which the p-value is 0.000 . It is a real form of an attitude that is understood by a person, a person who receives stimulus will be implemented in the form of action.

Statistical test results show a significant correlation between the actions of the society preparedness against earthquake and Tsunami, in which the p-value is 0.000 . It is similar to Novria's research (2018), which found a significant relationship between training with society preparedness in the face of the earthquake and Tsunami in which the p-value is 0.004 . Training is an important factor that is decisive in assessing society preparedness in the face of the earthquake and Tsunami [19].

In this study, the variables that most influence disaster preparedness is training with a $p$ value of 0.000 . In line with research conducted by Novria (2019) that training is the dominant factor of the earthquake and tsunami preparedness with a p-value of 0.001 . Training can be used to see how much the readiness of society to cope with disasters. Training can be formed from such small scales among each village or neighborhood.

The well-trained communities will be better prepared for the earthquake and Tsunami compared to the communities that have not been trained. Therefore, it is expected that related parties can improve the preparedness of society to face up earthquake and tsunami disasters [19].

\section{Conclusion}

More than half of respondents (56.6\%) were not ready for preparedness in facing the earthquake and tsunami potential of the west coast of Padang 2019. Nearly half of the respondents $(42.5 \%)$ had a low level of knowledge in the area in facing the earthquake and Tsunami. Half of the respondents $(48.1 \%)$ had a negative attitude in facing the earthquake and tsunami potential of the west coast of Padang area 2019. Less than half of respondents $(23.6 \%)$ have less experience in dealing with earthquakes and Tsunami of the west coast of Padang area 2019. Less than half of respondents $(23.6 \%)$ had a low education level. More than half of respondents $(53.8 \%)$ were female. Almost half of the respondents $(44,3 \%)$ had no appropriate action in facing the earthquake and Tsunami. Almost half of the respondents (48.1\%) had never attended training in the preparedness of earthquake and Tsunami.

Variable knowledge, level of education, action, and training were related to tsunami preparedness regarding the potential area of the west coast of Padang Year 2019. Variable attitude, experience, the sex were not associated with a potential tsunami preparedness on the west coast region of Padang in 2019. And the factors that most affect preparedness is the training variable. It is expected for the stakeholders to improve society preparedness in the face of the earthquake and Tsunami. 


\section{Acknowledgment}

Thank you for all of the respondents who had involved and had an active role in this study. Hopefully, it will give positive energy for us to increase society preparedness to face up earthquake and Tsunami in Padang City.

\section{References}

[1] Ministry of Health of the Republic of Indonesia http://pusatkrisis.kemenkes.go.id, Why the West Sumatra Earthquake Prone [April 25 2019]

[2] The Government of the Republic of Indonesia. Act 24 of 2007 on Disaster Management. Jakarta: Indonesian Government; 2007.

[3] Saparinto, Floreal, Hidayanti D. Food Additives. Yogyakarta: Canisius; 2006.

[4] Disaster management Agency(BPBD). Annual Report 2017 PUSDALOPS-PB West Sumatra. Padang:BNPB West Sumatra; 2017.

[5] Center for Volcanology and Geological Hazard Mitigation. Map Disaster Prone Region:http://vsi.esdm.go.id; 2016 [25 April 2019]

[6] National Disaster Management Authority. Agile Response Handbook Disaster Resilient: BNPB;2017.

[7] Notoatmodjo S. Health Promotion: Theory and Applications. Jakarta: PT. Rineka Reserved; 2005.

[8] S. Notoatmodjo Into Health Promotion and Behaviorhealth is. Jakarta: PT. Rineka Reserved; 2012.

[9] Gozeva T. Knowledge and Perception on Seismic Risk of Students in Mexico City Before the 2017 Earthquakes. 2017.

[10] Notoatmodjo S. Education and Health Behavior. Jakarta: PT. Rineka Reserved; 2003.

[11] Susilawati N. Knowledge and Support Relationships with Family Members Domestic Preparedness in Disaster Earthquake in Hamlet Soronanggan Panjangrejo Pundong Bantul [thesis]. Yogyakarta: Aisyiyah STIKES; 2015.

[12] Marseli HT. Factor-the factors Related to Power Puskesmas preparedness in the face of the earthquake and Tsunami Padang Year 2017 [thesis]. Padang: Andalas University; 2017.

[13] Alhusna A. Factors relating to the Flood Disaster Preparedness in the village of Lubuk Buaya Koto subdistrict Tangah Year 2017 [thesis]. Padang: Andalas University; 2017.

[14] Havwina T, EnokMariani, Nandi. Disaster Preparedness Experiences Influence on Students inFacing Threats Earthquake and Tsunami. Jurnal Education Geography. 2016; 16 (2): 124-131.

[15] Afifah I. Risk Perception Study Housewife Earthquake in RW 02, Village South Jakarta Menteng in 2011 [thesis]. Jakarta: Indonesian University; 2011.

[16] Pokharel A. Knowledge Regarding Earthquake Preparedness Among the People of Biratnagar Sub Metropolis of Eastern Nepal. Scar Journal of Health Sciences. 2017; 2 (2): 201- 205.

[17] Syahrizal. Influence Knowledge, Attitudes and Education Chief of Preparedness Against Family Home Risks Facing the Tsunami In the village of Ulee Lheue Meuraxa Banda Aceh in 2013 [thesis]. Terrain: The University of West Sumatra; 2013. 
[18] Singh SSALB, Rathakrishnan B. Assessment of Knowledge and Willingness Disaster Gempa School Teachers Earth in circles in Ranau, Sabah. Social Science and Humanities. 2018; 13 (2): 73-88.

[19] Novria et al. Factors associated with a midwife in Disaster Preparedness Earthquake and Tsunami in Puskesmas Padang [thesis]. Padang: Andalas University; 2018. 